\title{
Digestibility markers of sheep diets containing hydrolyzed sugarcane-top hay ${ }^{1}$
}

\author{
Indicadores de digestibilidade de dietas para ovinos contendo feno de ponta de cana- \\ de-açúcar hidrolisado
}

\author{
MOREIRA FILHO, Miguel Arcanjo ${ }^{2 *}$; ALVES, Arnaud Azevêdo²; GARCEZ, Bruno \\ Spíndola $^{2}$; MOREIRA, Antonia Leidiana ${ }^{2}$; AZEVÊDO, Danielle Maria Machado \\ Ribeiro $^{3}$; PARENTE, Henrique Nunes ${ }^{4}$
}

\footnotetext{
${ }^{1}$ Parte da tese de doutorado em Ciência Animal, na UFPI, do primeiro autor.

${ }^{2}$ Universidade Federal do Piauí, Centro de Ciências Agrárias, Departamento de Zootecnia, Teresina, Piauí, Brasil.

${ }^{3}$ Empresa Brasileira de Pesquisa Agropecuária, Centro de Pesquisa Agropecuária do Meio-Norte, Teresina, Piauí, Brasil.

${ }^{4}$ Universidade Federal do Maranhão, Centro de Ciências Agrárias e Ambientais, Chapadinha, Maranhão, Brasil.

*Endereço para correspondência: miguelarcanjo@agronomo.eng.br
}

\section{SUMMARY}

This experiment evaluated the correlation between the estimates of fecal digestibility and dry matter digestibility (DMD) and nutrients obtained using internal (indigestibles dry materiDM, neutral detergent fiber-iNDF, acid detergent fiber-iADF and acid detergent ligniniADL) and external (chromium oxide- $\mathrm{Cr}_{2} \mathrm{O}_{3}$, titanium dioxide- $\mathrm{TiO}_{2}$, and purified and enriched lignin from eucalyptus-LIPE ${ }^{\circledR}$ ) markers and the values obtained by the total feces collection method. Twenty uncastrated male sheep, with $29.64 \pm 5.53 \mathrm{~kg}$ average live weight; approximately 12 months old, were kept in metabolic cages and fed diets containing untreated sugarcane-top hay or sugarcane-top hay hydrolyzed with 3 and $6 \%$ urea or 1.5 and $3 \%$ calcium oxide $(\mathrm{CaO})$. There was a positive correlation $(\mathrm{P}<.05)$ between the fecal production estimated by the markers and via total feces collection, with coefficients higher than $90 \%$ for iDM, $\mathrm{Cr}_{2} \mathrm{O}_{3}$, and $\mathrm{TiO}_{2}$. The DMD and nutrients estimated with the use of markers was positively correlated $(\mathrm{P}<.05)$ with that obtained by total feces collection. Coefficients of correlation for digestibility obtained by total collection were higher than those obtained with $\mathrm{Cr}_{2} \mathrm{O}_{3}$, but close to those obtained using $\mathrm{TiO}_{2}$. The coefficient of correlation between the digestibility of protein and fiber fraction estimated with iDM and iNDF and that obtained by total collection was higher than $70 \%$. Internal marker iDM and external markers $\mathrm{Cr}_{2} \mathrm{O}_{3}$ and $\mathrm{TiO}_{2}$ are effective in estimating fecal production and DMD and nutrients.

Keywords: chemist treatment, external markers, internal markers, total collection, Saccharum officinarum L.

\section{RESUMO}

Avaliou-se a correlação das estimativas de produção fecal e digestibilidade da matéria seca (DMS) e nutrientes obtidas por indicadores internos (matéria seca-MSi, fibra em detergente neutro-FDNi, fibra em detergente ácido-FDAi e lignina em detergente ácido-LDAi indigestíveis) e externos (óxido de cromo- $\mathrm{Cr}_{2} \mathrm{O}_{3}$, dióxido de titânio- $\mathrm{TiO}_{2}$ e lignina purificada e enriquecida de eucalipto-LIPE ${ }^{\circledR}$ ) com valores obtidos pelo método de coleta total de fezes. Utilizaram-se 20 ovinos, machos, não castrados, com 29,64 \pm $5,53 \mathrm{~kg}$ de peso vivo médio e aos 12 meses de idade, mantidos em gaiolas metabólicas e alimentados com rações compostas por feno de ponta de cana-de-açúcar não tratado ou hidrolisado com 3 e $6 \%$ de ureia ou 1,5 e $3 \%$ de óxido de cálcio $(\mathrm{CaO})$. Houve correlação positiva $(\mathrm{P}<0,05)$ da produção fecal estimada pelos indicadores com a coleta total de fezes, 
com coeficientes maiores de $90 \%$ para $\mathrm{MSi}$, $\mathrm{Cr}_{2} \mathrm{O}_{3}$ e $\mathrm{TiO}_{2}$. A digestibilidade da $\mathrm{MS}$ e de nutrientes estimada a partir do uso de indicadores correlacionou-se positivamente com a obtida pela coleta total de fezes. Maiores coeficientes de correlação foram obtidos para a digestibilidade por coleta total em relação ao $\mathrm{Cr}_{2} \mathrm{O}_{3}$, com valores aproximados aos obtidos para $\mathrm{TiO}_{2}$. Quanto aos indicadores internos MSi e FDNi, a digestibilidade da proteína e fração fibrosa apresentou coeficiente de correlação com a digestibilidade por coleta total superior a $70 \%$. O indicador interno MSi e os externos $\mathrm{Cr}_{2} \mathrm{O}_{3}$ e $\mathrm{TiO}_{2}$ são eficazes na estimativa da produção fecal e digestibilidade da MS e nutrientes.

Palavras-chave: coleta total, indicadores externos, indicadores internos, Saccharum officinarum L., tratamento químico

\section{INTRODUCTION}

The practice of determining the dry matter digestibility (DMD) of and nutrients through in vivo assays with total feces collection has been adopted over the years, despite being a laborious and costly experimental method, especially due to the need to manipulate large volumes of samples and greater care in handling the animals (BRITO et al., 2007). Therefore, markers have been employed (OLIVEIRA et al., 2012; SOUSA et al., 2015), indigestible chemical components of feeds (internal markers) or that can be added to diets (external markets), and both should be completely retrievable in the feces.

Indigestible DM and the components of the feed fibrous fractions (iNDF, iADF and $\mathrm{iADL}$ ) have been evaluated as internal markers (SILVA et al., 2010; MAEDA et al., 2011). The recovery of these indigestible fractions of the feed is the basis for the efficiency of these internal markers, which are achieved in in situ with incubation in the rumen, usually up to $264 \mathrm{~h}$ (MAEDA et al., 2011).

Among the external markers, chromium oxide $\left(\mathrm{Cr}_{2} \mathrm{O}_{3}\right)$, titanium dioxide $\left(\mathrm{TiO}_{2}\right)$, and purified and enriched lignin from eucalyptus (LIPE®) have been the most used in estimates of digestibility, however, their passage rate is different from those of the components of feeds. $\mathrm{Cr}_{2} \mathrm{O}_{3}$ is a noteworthy example of this, because there is a likely diurnal variation in the fecal excretion of this marker that may lead to variations in the estimate of the fecal DM production and in vivo digestibility if the number of daily collections is reduced (SOUZA et al., 2015).

Indicators of fecal production, intake and digestibility must be sought, given their different responses regarding their recovery in the feces and potential to estimate total fecal DM production and digestibility in ruminants, which is related to experimental conditions concerning animals, type of diet, type of marker, and association between markers and diets (RODRIGUES et al., 2010). So it is necessary evaluate the estimates total fecal DM production and of digestibility obtained by the different internal and external indicators digestibility compared to the total collection of feces.

In this context, it is important to evaluate digestibility markers when using stubble from crops treated by hydrolytic methods in sheep diets. Thus, was objective evaluate the efficiency, by correlation of Pearson, of internal and external markers in estimating the total fecal DM production and the DMD and nutrients in sheep fed with diets containing hydrolyzed sugarcane-top hay. 


\section{MATERIALS AND METHODS}

The experiment was conducted in the Metabolism Shed and analyses were performed in the Laboratory of Animal Nutrition at the Department of Animal Science at Agricultural Science Center of Federal University of Piauí located in Teresina/PI, Brazil.

To making hay, the sugarcane top was harvested, from a first-cut canebrake from Associação Campestre Norte, in Teresina/PI, and transported to Animal Science at Agricultural Science Center of Federal University of Piauí, where it was ground in a forage shredding machine without sieve and hayed in the sun for two days.

Twenty intact male crossbred (undefined breed [UB] $\times$ Santa Inês) sheep $(29.64 \pm 5.53 \mathrm{~kg}$ average live weight; approximately 12 months old) in good sanitary and nutritional conditions were kept in metabolic cages with access to the diets containing untreated sugarcane-top hay or sugarcane-top hay hydrolyzed with 3 and $6 \%$ urea or 1.5 and $3 \%$ calcium oxide $(\mathrm{CaO})$, on a DM basis, which were supplied at $08 \mathrm{~h} 00$ and $15 \mathrm{~h} 00$, so as to provide $20 \%$ orts in relation to the intake of the previous day. Water and mineral supplement were available ad libitum.

For the ammonization, the urea was dissolved in enough water to elevate the hay moisture content to $30 \%$ (GOBBI et al., 2005), and then distributed evenly over the material using a watering can. The urea-treated hay was properly conditioned in an open and airy place on wooden platforms and sealed with plastic canvas. After ammonia, had been acting for 35 days, the canvas was removed and the material was subjected to aeration for $48 \mathrm{~h}$ aiming to eliminate the excess residual ammonia.

In the treatments with $\mathrm{CaO}$, it was diluted in enough water to elevate the moisture content of the forage to approximately $70 \%$ (RIBEIRO et al., 2009). The treated material was conditioned in plastic buckets (200-mL drums) that remained in an open and airy environment for $28 \mathrm{~h}$. Next, the forage was dried in the sun for $12 \mathrm{~h}$ to obtain the ideal moisture for storage (12 to $20 \%$ ) and to be supplied later to the animals.

After the period of aeration and drying, the untreated sugarcane-top hay and the sugarcane-top hay hydrolyzed with urea and $\mathrm{CaO}$ were ground in forage shredding machine with a sieve to particles measuring 2.5 to $3.0 \mathrm{~cm}$. This material was the roughage base of the total, isoproteic, isocaloric diets for finishing sheep, with a roughage:concentrate ratio of 40:60, balanced according to the NRC (2007) for a daily gain of $300 \mathrm{~g}$. The chemical and centesimal compositions of ingredients and diets are shown in Tables 1 and 2.

Supplied diets, orts, and feces were collected for five days, preceded by a seven-day period of acclimatization to facilities, nocturnal illumination and diets, totaling twelve experimental days. Orts were collected before each meal, and feces were collected after the diets were supplied (at 09h00 and 16h00), using samples of $20 \%$ that were conditioned in plastic bags and preserved in a freezer $\left(-5\right.$ to $\left.-10^{\circ} \mathrm{C}\right)$.

At the end of the collection period, samples were thawed and homogenized, thus forming composite samples per animal, which were then pre-dried in a forced-ventilation oven at $60 \pm 5^{\circ} \mathrm{C}$, for $72 \mathrm{~h}$ and ground according to Detmann et al. (2012) in a Wiley mill to 1-mm particles for analysis of the fibrous fractions and external marker, and 2$\mathrm{mm}$ particles for incubation in the rumen and other chemical analyses.

The concentrations of DM as well as(on a DM basis) crude protein (CP), ether extract $(\mathrm{EE})$, mineral matter $(\mathrm{MM})$ and 
energy value were determined according to methodologies of the AOAC (2012); neutral detergent fiber (NDFap), according to the methodology of Van Soest et al. (1991) and acid detergent fiber (ADFap), according to the methodology of Van Soest et al. (1963),corrected for ash and protein; acid detergent lignin contents (ADL) were calculated by the method of Van Soest et al. (1963); and neutral (NDIN) and acid (ADIN) detergent insoluble contents were determined according to methodologies described by Licitra et al. (1996).

Concentration of cellulose (CEL) and hemicellulose (HEM) were calculated using the following formulae: $\mathrm{CEL}=$
ADFap-LIG, and HEM = NDFapADFap, respectively. Non-fiber carbohydrate (NFC) and total carbohydrate (TC) contents were estimated using formulas proposed by Detmann \& Valadares Filho (2010), as follows: $\mathrm{NFC}=100-[(\% \mathrm{CP}-$ $\% \mathrm{CP}_{\text {urea }}+\%$ urea $)+\% \mathrm{NDFap}+\% \mathrm{EE}+$ $\% \mathrm{MM}]$ and $\mathrm{TC}=\mathrm{NFC}+\mathrm{NDF} a p$, where $\% \mathrm{CP}=$ dietary $\mathrm{CP} ; \% \mathrm{CP}_{\text {urea }}=\mathrm{CP}$ originated from the urea in the diet; and $\%$ urea $=\%$ of urea in the diet. The total digestible nutrient (TDN) content was calculated by the formula of Weiss et al. (1992), as follows: $\mathrm{TDN}(\%)=\mathrm{DCP} \%+\mathrm{DNDF} \%+\mathrm{NFC} \%$ $+(2.25 \times \mathrm{XEE} \%)$.

Table 1. Chemical composition of dietary ingredients

\begin{tabular}{|c|c|c|c|c|c|c|c|}
\hline Item & STH & $\mathrm{STH}_{\mathrm{U} 3 \%}$ & $\mathrm{STH}_{\mathrm{U} 6 \%}$ & $\mathrm{STH}_{\mathrm{CaO} .5 \%}$ & $\mathrm{STH}_{\mathrm{CaO} \%}$ & Corn & $\begin{array}{c}\text { Soybean } \\
\text { meal }\end{array}$ \\
\hline Dry matter $(\%$ of $\mathrm{NM})$ & 87.74 & 85.64 & 85.59 & 89.94 & 89.51 & 90.50 & 91.21 \\
\hline \multicolumn{8}{|c|}{$\%$ of DM } \\
\hline Crude protein & 4.60 & 10.36 & 17.46 & 5.19 & 4.18 & 8.72 & 49.58 \\
\hline Ether extract & 1.24 & 0.88 & 0.89 & 1.60 & 1.37 & 4.14 & 0.91 \\
\hline Mineral matter & 5.57 & 5.45 & 4.37 & 7.52 & 7.64 & 1.24 & 6.96 \\
\hline NDFap & 80.32 & 78.77 & 74.46 & 78.15 & 80.99 & 10.98 & 14.35 \\
\hline ADFap & 47.52 & 48.90 & 46.10 & 45.52 & 48.84 & 4.62 & 9.77 \\
\hline Hemicellulose & 32.80 & 29.87 & 28.36 & 32.63 & 32.15 & 6.36 & 4.58 \\
\hline Cellulose & 42.11 & 43.90 & 41.80 & 41.11 & 42.99 & 3.59 & 8.31 \\
\hline $\mathrm{ADL}$ & 5.41 & 5.00 & 4.30 & 4.41 & 5.85 & 1.03 & 1.46 \\
\hline Total carbohydrates & 88.59 & 87.02 & 85.57 & 85.69 & 86.81 & 85.90 & 42.55 \\
\hline NFC & 8.27 & 8.25 & 11.11 & 7.54 & 5.82 & 74.92 & 28.20 \\
\hline \multicolumn{8}{|c|}{$\%$ of the total $\mathrm{N}$} \\
\hline NDIN & 31.73 & 23.95 & 21.18 & 31.27 & 29.86 & 3.75 & 5.70 \\
\hline ADIN & 23.35 & 17.68 & 12.14 & 25.88 & 27.84 & 1.57 & 2.71 \\
\hline \multicolumn{8}{|c|}{$\begin{array}{l}\mathrm{STH}=\text { non-hydrolyzed sugarcane-top hay; } \mathrm{STH}_{\mathrm{U} 3 \%}=\text { sugarcane-top hay hydrolyzed with } 3 \% \text { urea; } \mathrm{STH}_{\mathrm{U} 6 \%}= \\
\text { sugarcane-top hay hydrolyzed with } 6 \% \text { urea; } \mathrm{STH}_{\mathrm{CaO} .5 \%}=\text { sugarcane-top hay hydrolyzed with } 1.5 \% \text { calcium } \\
\text { oxide; } \mathrm{STH}_{\mathrm{CaO} 3 \%}=\text { sugarcane-top hay hydrolyzed with } 3 \% \text { calcium oxide; } \mathrm{NM}=\text { natural matter; } \mathrm{N}=\text { nitrogen; } \\
\mathrm{NDFap}=\text { neutral detergent fiber corrected for ash and protein; } \mathrm{ADFap}=\text { acid detergent fiber corrected for ash } \\
\text { and protein; } \mathrm{ADL}=\text { acid detergent lignin; } \mathrm{NDIN}=\text { neutral detergent insoluble nitrogen; } \mathrm{NFC}=\text { non-fiber } \\
\text { carbohydrates; ADIN = acid detergent insoluble nitrogen. }\end{array}$} \\
\hline
\end{tabular}


Rev. Bras. Saúde Prod. Anim., Salvador, v.18, n.1, p.38-49 jan./mar., 2017

ISSN 15199940 http://mc04.manuscriptcentral.com/rbspa-scielo http://dx.doi.org/10.1590/S1519-99402017000100005

Table 2. Centesimal and chemical composition of the diets

\begin{tabular}{|c|c|c|c|c|c|}
\hline \multirow{2}{*}{ Ingredient/nutrient } & \multicolumn{5}{|c|}{ Diets } \\
\hline & STH & $\mathrm{STH}_{\mathrm{U} 3 \%}$ & $\mathrm{STH}_{\mathrm{U} 6 \%}$ & $\mathrm{STH}_{\mathrm{CaO1.5}} \%$ & $\mathrm{STH}_{\mathrm{CaO} 3 \%}$ \\
\hline \multicolumn{6}{|c|}{ Centesimal composition } \\
\hline Non-hydrolyzed STH (STH) & 40.23 & 0.00 & 0.00 & 0.00 & 0.00 \\
\hline STH with $3 \%$ urea $\left(\mathrm{STH}_{\mathrm{U} 3}\right)$ & 0.00 & 40.37 & 0.00 & 0.00 & 0.00 \\
\hline STH with $6 \%$ urea $\left(\mathrm{STH}_{\mathrm{U} 6}\right)$ & 0.00 & 0.00 & 40.00 & 0.00 & 0.00 \\
\hline STH with $1.5 \% \mathrm{CaO}\left(\mathrm{STH}_{\mathrm{CaO} 1.5}\right)$ & 0.00 & 0.00 & 0.00 & 40.23 & 0.00 \\
\hline STH with $3 \% \mathrm{CaO}\left(\mathrm{STH}_{\mathrm{CaO} 3}\right)$ & 0.00 & 0.00 & 0.00 & 0.00 & 40.13 \\
\hline Soybean meal & 20.96 & 19.81 & 14.01 & 20.53 & 21.42 \\
\hline Ground corn grain & 38.18 & 39.76 & 45.93 & 38.70 & 37.91 \\
\hline Urea & 0.57 & 0.00 & 0.00 & 0.48 & 0.48 \\
\hline Flower of sulfur & 0.06 & 0.06 & 0.06 & 0.06 & 0.06 \\
\hline \multicolumn{6}{|c|}{ Chemical composition } \\
\hline Dry matter (\% fresh matter) & 89.60 & 88.68 & 88.64 & 90.47 & 90.31 \\
\hline \multicolumn{6}{|c|}{$\%$ of the DM } \\
\hline Crude protein & 17.17 & 17.47 & 17.94 & 17.00 & 16.95 \\
\hline Ether extract & 2.27 & 2.18 & 2.38 & 2.43 & 2.31 \\
\hline Mineral matter & 4.17 & 4.07 & 3.29 & 4.93 & 5.03 \\
\hline NDFap & 39.51 & 39.01 & 36.84 & 38.64 & 39.74 \\
\hline ADFap & 22.93 & 23.51 & 21.93 & 22.11 & 23.44 \\
\hline Hemicellulose & 16.58 & 15.49 & 14.91 & 16.53 & 16.29 \\
\hline Cellulose & 20.05 & 20.80 & 19.53 & 19.63 & 20.39 \\
\hline ADL & 2.88 & 2.72 & 2.40 & 2.47 & 3.05 \\
\hline Total carbohydrates & 77.35 & 77.71 & 79.64 & 76.45 & 76.52 \\
\hline Non-fiber carbohydrates & 37.84 & 38.71 & 42.81 & 37.82 & 36.78 \\
\hline \multicolumn{6}{|c|}{$\%$ of the total $\mathrm{N}$} \\
\hline Neutral detergent insoluble nitrogen & 15.39 & 12.29 & 10.99 & 15.20 & 14.63 \\
\hline Acid detergent insoluble nitrogen & 10.56 & 8.30 & 5.96 & 11.58 & 12.35 \\
\hline
\end{tabular}

$\mathrm{STH}=$ non-hydrolyzed sugarcane-top hay; $\mathrm{STH}_{\mathrm{U} 3 \%}=$ sugarcane-top hay hydrolyzed with $3 \%$ urea; $\mathrm{STH}_{\mathrm{U} 6 \%}=$ sugarcane-top hay hydrolyzed with $6 \%$ urea; $\mathrm{STH}_{\mathrm{CaO1.5} \%}=$ sugarcane-top hay hydrolyzed with $1.5 \%$ calcium oxide; $\mathrm{STH}_{\mathrm{CaO} 3 \%}=$ sugarcane-top hay hydrolyzed with $3 \%$ calcium oxide; $\mathrm{N}=$ nitrogen; $\mathrm{NDF} a \mathrm{p}=$ neutral detergent fiber corrected for ash and protein; ADFap $=$ acid detergent fiber corrected for ash and protein; $\mathrm{ADL}=$ acid detergent lignin; $\mathrm{NDIN}=$ neutral detergent insoluble nitrogen; $\mathrm{ADIN}=$ acid detergent insoluble nitrogen.

The total fecal DM production and digestibility of DM and nutrients were estimated by the total feces collection method and compared with those obtained with use of internal markers, represented by the indigestible components iDM, iNDF, iADF and iADL, and external markers $\mathrm{Cr}_{2} \mathrm{O}_{3}$, $\mathrm{TiO}_{2}$, and $\mathrm{LIPE}^{\circledR}$, which corresponded to the treatments, in which all indicators were administered and/or evaluated in each animal, together with the total fecal collection.
The apparent digestibility of $\mathrm{DM}, \mathrm{CP}$, EE, NDF, ADF, HEM, CEL, NFC, TC, and $\mathrm{EB}$ by total feces collection were obtained with the following formula: $\operatorname{Dig}(\%)=\left[\left(\mathrm{N}_{\mathrm{IN}}-\mathrm{N}_{\mathrm{F}}\right) / \mathrm{N}_{\mathrm{IN}}\right] \times 100$, where $\mathrm{N}_{\mathrm{IN}}=$ nutrient ingested; and $\mathrm{N}_{\mathrm{F}}=$ nutrient in the feces.

The external makers were administered orally, simultaneously to the 20 animals, using a PVC tube, always at $14 \mathrm{~h}$ (before each meal) (KOZLOSKI et al., 2006) and for the entire collection period (five days). $\mathrm{Cr}_{2} \mathrm{O}_{3}$ and $\mathrm{TiO}_{2}$ were administered in a 
single dose of $4 \mathrm{~g} / \mathrm{animal} / \mathrm{day}$, preceded by a period of acclimatization of seven days; LIPE $^{\circledR}$ was supplied at 250 $\mathrm{mg}$ /animal/day, with two days for adaptation.

The $\mathrm{Cr}_{2} \mathrm{O}_{3}$ in the feces was determined by atomic absorption spectrophotometry, while $\mathrm{TiO}_{2}$ was determined with an UV/visible spectrophotometer, according to methodologies described by Detmann et al. (2012). LIPE $^{\circledR}$ was analyzed in the Laboratory of Animal Nutrition of the Veterinary School at Federal University of Minas Gerais by near-infrared spectroscopy, according to Saliba (2001). To evaluate the internal markers, samples of diet, orts and feces were incubated in a fistulated cow for $264 \mathrm{~h}$ (CASALI et al., 2008), using $12.0 \times$ $8.0 \mathrm{~cm}$ nylon bags with $50 \mu \mathrm{m}$ porosity containing approximately $4 \mathrm{~g}$ of the sample ground in a $2.0 \mathrm{~mm}$ sieve. After the incubation period, bags were washed in running water and dried in a forced air-circulation oven at $60 \pm 5^{\circ} \mathrm{C}$ for $72 \mathrm{~h}$ for later analyses of the indigestible DM fraction (AOAC, 2012), NDF (VAN SOEST et al., 1991) and ADF and ADL(VAN SOEST et al., 1963).

To calculate the fecal recovery of the markers (REC) and the estimate of the total fecal DM production (FP), with the use of markers, the formulae described by Zeoula et al. (2002) were adopted, as follows: $\mathrm{REC}(\%)=\left(\mathrm{FP}_{\mathrm{M}} / \mathrm{FP}_{\mathrm{TC}}\right) \times 100$ and $\mathrm{FP}(\mathrm{g} /$ day $)=\mathrm{MI} / \mathrm{MF}$, where $\mathrm{FP}_{\mathrm{M}}=$ fecal production estimated by the marker (gDM/day); $\quad \mathrm{FP}_{\mathrm{TC}}=$ fecal production estimated by total feces collection (gDM/day); $\mathrm{MI}=$ marker ingested ( $\mathrm{g} /$ day); and $\mathrm{MF}=$ marker in the feces $(\mathrm{g} / \mathrm{gDM})$.

Based on the total fecal DM production data, the digestibility was estimated by the internal or external markers $\left(\operatorname{Dig}_{M}\right)$, employing the formula described Zeoula et al. (2002), as follows: $\operatorname{Dig}_{M}(\%)=$ $\left[\left(\mathrm{N}_{\mathrm{MN}}-\mathrm{N}_{\mathrm{F}}\right) / \mathrm{N}_{\mathrm{IN}}\right] \times 100$. The nutrients in the fecal DM estimated with the use of markers were obtained by the following formula: $\mathrm{N}_{\mathrm{F}}(\mathrm{g})=\left(\mathrm{FP}_{\mathrm{M}} \mathrm{x} \% \mathrm{~N}_{\mathrm{F}}\right) / 100$.

The design was adopted in randomized blocks, according to animal weights intervals (five blocks), with eight treatments (methods of total feces collection and internal indicators iDM, iNDF, iADF and iADL and external $\mathrm{Cr}_{2} \mathrm{O}_{3}, \mathrm{TiO}_{2}$ and $\mathrm{LIPE}^{\circledR}$ ), with twenty repetitions (animals). Pearson's correlation analysis was applied to the data, employing the CORR procedure of SAS (2002) at a significance level of 5\%.

\section{RESULTS AND DISCUSSION}

The total fecal DM estimated by internal marker iDM and external markers $\mathrm{Cr}_{2} \mathrm{O}_{3}$ and $\mathrm{TiO}_{2}$ showed a positive correlation $(\mathrm{P}<0.05)$ of 0.9373 ; 0.9498 and 0.9236 , respectively, with the fecal DM obtained by total feces collection (Table 3), however, was observed correlation $(\mathrm{P}<0.05)$ of more than 0.70 with the digestibility of DM and nutrients (Table 4) only with use de $\mathrm{Cr}_{2} \mathrm{O}_{3}$. The accuracy in the determination of total fecal DM estimated by the iDM, $\mathrm{Cr}_{2} \mathrm{O}_{3}$ and $\mathrm{TiO}_{2}$ markers is consistent with their fecal recovery. According to Rodrigues et al. (2010), the closer they are to the recovery obtained by the total collection $(100 \%)$, the more precise the marker.

The estimates of total fecal DM using iADL and LIPE ${ }^{\circledR}$ had a low correlation with that obtained by total feces collection $(\mathrm{r}=0.5351$ and $\mathrm{r}=0.4200$, respectively; $\mathrm{P}<0.05)$, which may compromise the determination of the digestibility coefficients with the use of these markers. 
Table 3. Fecal recovery of the markers (\% of fecal DM), and correlation between total fecal dry matter production estimated with the use of markers and that obtained by total collection from sheep fed diets containing hydrolyzed sugarcane-top hay

\begin{tabular}{|c|c|c|c|c|c|c|c|}
\hline & iDM & iNDF & iADF & iADL & $\mathrm{Cr}_{2} \mathrm{O}_{3}$ & $\mathrm{TiO}_{2}$ & LIPE $^{(}$ \\
\hline REC & $\begin{array}{c}122.1 \pm 1 \\
2.0\end{array}$ & $126.9 \pm 13.7$ & $140.0 \pm 20.7$ & $185.9 \pm 38.7$ & $92.5 \pm 6.6$ & $85.0 \pm 8.3$ & $76.1 \pm 15.7$ \\
\hline $\mathrm{TC}$ & 0.9373 & 0.8849 & 0.7614 & 0.5351 & 0.9498 & 0.9236 & 0.4200 \\
\hline $\mathrm{P}$ & $<0.0001$ & $<0.0001$ & $<0.0001$ & 0.0151 & $<0.0001$ & $<0.0001$ & 0.0652 \\
\hline
\end{tabular}

$\mathrm{iDM}=$ indigestible dry matter; $\mathrm{iNDF}=$ indigestible neutral detergent fiber; $\mathrm{iADF}=$ indigestible acid detergent fiber; $\mathrm{iADL}=$ indigestible lignin; $\mathrm{Cr}_{2} \mathrm{O}_{3}=$ chromium oxide; $\mathrm{TiO}_{2}=$ titanium dioxide; $\mathrm{LIPE}^{\circledR}=$ purified and enriched lignin from eucalyptus; $\mathrm{TC}=$ total feces collection method; $\mathrm{REC}=$ fecal recovery of the marker; $\mathrm{P}=$ statistical probability.

Table 4. Correlation between the digestibility of dry matter and nutrients estimated by total fecal dry matter production with the use of markers and that obtained by the total collection from sheep fed diets containing hydrolyzed sugarcane-top hay

\begin{tabular}{|c|c|c|c|c|c|}
\hline Parameter & iDM & iNDF & iADF & $\mathrm{Cr}_{2} \mathrm{O}_{3}$ & $\mathrm{TiO}_{2}$ \\
\hline & \multicolumn{5}{|c|}{ Dry matter digestibility } \\
\hline Total collection & 0.5101 & 0.5486 & 0.2501 & 0.7300 & 0.4199 \\
\hline \multirow[t]{2}{*}{$\mathrm{P}$} & 0.0216 & 0.0122 & 0.2876 & 0.0003 & 0.0653 \\
\hline & \multicolumn{5}{|c|}{ Crude protein digestibility } \\
\hline Total collection & 0.8943 & 0.8576 & 0.7850 & 0.9182 & 0.8580 \\
\hline \multirow[t]{2}{*}{$\mathrm{P}$} & $<0.0001$ & $<0.0001$ & $<0.0001$ & $<.0001$ & $<0.0001$ \\
\hline & \multicolumn{5}{|c|}{ Ether extract digestibility } \\
\hline Total collection & 0.9696 & 0.9705 & 0.9294 & 0.9860 & 0.9744 \\
\hline \multirow[t]{2}{*}{$\mathrm{P}$} & $<0.0001$ & $<0.0001$ & $<0.0001$ & $<0.0001$ & $<0.0001$ \\
\hline & \multicolumn{5}{|c|}{ Neutral detergent fiber digestibility } \\
\hline Total collection & 0.7397 & 0.7253 & 0.5504 & 0.8942 & 0.7116 \\
\hline \multirow[t]{2}{*}{$\mathrm{P}$} & 0.0002 & 0.0003 & 0.0119 & $<0.0001$ & 0.0004 \\
\hline & \multicolumn{5}{|c|}{ Acid detergent fiber digestibility } \\
\hline Total collection & 0.8425 & 0.8100 & 0.7373 & 0.9364 & 0.7782 \\
\hline \multirow[t]{2}{*}{$\mathrm{P}$} & $<0.0001$ & $<0.0001$ & 0.0002 & $<0.0001$ & $<0.0001$ \\
\hline & \multicolumn{5}{|c|}{ Non-fiber carbohydrate digestibility } \\
\hline Total collection & 0.8549 & 0.8755 & 0.7682 & 0.8902 & 0.8459 \\
\hline \multirow[t]{2}{*}{$\mathrm{P}$} & $<0.0001$ & $<0.0001$ & $<0.0001$ & $<0.0001$ & $<0.0001$ \\
\hline & \multicolumn{5}{|c|}{ Cellulose digestibility } \\
\hline Total collection & 0.7818 & 0.7762 & 0.6704 & 0.9406 & 0.8020 \\
\hline \multirow[t]{2}{*}{$\mathrm{P}$} & $<0.0001$ & $<0.0001$ & 0.0012 & $<0.0001$ & $<0.0001$ \\
\hline & \multicolumn{5}{|c|}{ Hemicellulose digestibility } \\
\hline Total collection & 0.7930 & 0.7757 & 0.6569 & 0.9173 & 0.8497 \\
\hline \multirow[t]{2}{*}{$\mathrm{P}$} & $<0.0001$ & $<0.0001$ & 0.0017 & $<0.0001$ & $<0.0001$ \\
\hline & \multicolumn{5}{|c|}{ Energy digestibility } \\
\hline Total collection & 0.5059 & 0.5247 & 0.2410 & 0.7282 & 0.3775 \\
\hline \multirow[t]{2}{*}{$\mathrm{P}$} & 0.0229 & 0.0175 & 0.3060 & 0.0003 & 0.1008 \\
\hline & \multicolumn{5}{|c|}{ Total digestible nutrients } \\
\hline Total collection & 0.5704 & 0.6228 & 0.2737 & 0.7715 & 0.5705 \\
\hline $\mathrm{P}$ & 0.0086 & 0.0034 & 0.2429 & $<0.0001$ & 0.0086 \\
\hline
\end{tabular}

$\mathrm{iDM}=$ indigestible dry matter; iNDF $=$ indigestible neutral detergent fiber; $\mathrm{iADF}=$ indigestible acid detergent fiber; $\mathrm{Cr}_{2} \mathrm{O}_{3}=$ chromium oxide; $\mathrm{TiO}_{2}=$ titanium dioxide; $\mathrm{P}=$ statistical probability. 
Internal markers (iDM, iNDF, iADF, and $\mathrm{iADL}$ ) resulted in an overestimated total fecal DM production, with their fecal recovery exceeding $100 \%$ (Table 3 ), which may associated with the greater concentration of these nutrients in the sugarcane-top hay. The fecal recovery of the external markers was below $100 \%$ is attributed to the partial absorption of the marker in the digestive tract or to its transformation into other compounds, which may cause an underestimate of the total fecal DM production.

The fecal recovery of iDM was the one that was closest to $100 \%$, which was obtained with total feces collection and was higher than that obtained by Kozloski et al. (2009). The use of iDM as a marker can provide exact results and high correlations with the total collection, never the less, the presence of contaminants may compromise the obtained results, since no detergent solutions are used to obtain the iDM content, which prevents the removal of residues from the cell wall and bacterial contamination. As consequence, the fecal recovery of this marker may be increased and the digestibility of diets may be underestimated.

The fecal recovery of iNDF was similar to that of iDM; however, it resulted in a correlation of $0.8849(\mathrm{P}<0.05)$, below 0.90, between total fecal DM production by iNDF and total collection. The full recovery of iADF $(\mathrm{r}=0.7614 ; \mathrm{P}<0.05)$ and $\mathrm{iADL}(\mathrm{r}=$ $0,5351 ; \mathrm{P}<0.05)$, in surpassed those estimated in sheep by Rodrigues et al. (2010), who obtained 0.9370 and 0.7440 , respectively.

Inappropriate variations and recoveries of iNDF, iADF, and iADL may be related to filtration problems during laboratory analyses (ZEOULA et al., 2002); however, thermostable $\alpha$ amylase and sodium sulfite were used in the determination of the fiber aiming at solubilizing the contaminating starch and $\mathrm{N}$, or also those inherent to the in situ digestion in the rumen, and according to Detmann et al. (2007), to the lower concentration of these markers in the chemical composition, which makes them sensitive to possible errors of analytical procedures.

The elevated fecal recovery of $\mathrm{iADF}$ and iADL had a direct influence on the low correlation between the total fecal DM production and digestibility estimated by these markers and those obtained by total feces collection. Thus, despite the practicality of the methodology of analysis of iADL, according to Silva et al. (2010), it may include a variety of nonlignin components, in addition to contaminants originating from the addition of additives, which may directly influence the determination of iADF. Furthermore, problems may arise due to the size of the feces particles, which are finer than the lignin and thus more prone to solubilization in the sulfuric acid. Therefore, these markers are to be used carefully in estimating total fecal DM production and digestibility.

Among the internal markers, iDM and iNDF showed the best correlation $(\mathrm{P}<0.05)$ for digestibility with that obtained by the total collection, with values above 0.70 for the digestibility of CP, NDF, ADF, HEM and CEL (Table 4). It is noteworthy the estimation of total fecal DM production with iDM had the highest correlation with the total collection; the fecal recovery of this marker was similar to that obtained with iNDF, but above $100 \%$, which may result in an overestimated total fecal DM production and consequently underestimated digestibility.

The use of iDM as a marker for the estimate of digestibility has been common in research with ruminants, and different effects have been 
observed, e.g., Torres et al. (2009), who obtained efficient estimates with iDM incubated for $144 \mathrm{~h}(61.24 \%)$ as compared with those obtained by total feces collection $(58.99 \%)$. According to Canesin et al. (2012), when internal markers are incubated for a shorter time, especially iDM, iNDF and iADF, they do not reproduce the indigestible fraction of the feed and consequently the digestibility of DM and nutrients, thus requiring longer incubation times. The recommended incubation time is 240 to $264 \mathrm{~h}$, with 2-mm particles.

Detmann et al. (2007) evaluated internal markers iDM, iNDF, and iADF in grazing cattle and found better estimates with iDM and iNDF for indirect evaluation of digestibility, whereas the values obtained by iADF showed variable effects with errors stemming from the analytical process, which affected its accuracy as a marker. Kozloski et al. (2009) observed a fecal recovery of iDM of $108.5 \%$, and no differences between the digestibility of organic matter estimated by that marker $(77.0 \%)$ and by total collection (76.00\%); however, these authors stress the little precision and variation in the estimate when changes are caused by experimental treatments.

Regarding the external markers, the fecal recovery of $\mathrm{Cr}_{2} \mathrm{O}_{3} \quad(92.5 \pm 6.6 \%)$ was higher, near $100 \%$, result similar to the 86.1 obtained by Rodrigues et al. (2010) in sheep also fed highconcentrate diets. Total fecal DM production can be estimated by the supply of $\mathrm{Cr}_{2} \mathrm{O}_{3}$ once daily in the afternoon, associated with collection of two fecal samples (one in the morning and another in the afternoon), because there is no variation in the concentration of this marker in the feces of cattle in collections performed at different times (KOZLOSKI et al., 2006). This is in line with the results obtained in this study with sheep under similar conditions of administration of marker and fecal collection.

The digestibility of DM and nutrients estimated with external marker $\mathrm{Cr}_{2} \mathrm{O}_{3}$ presented the best correlation with the digestibility by total collection, with recovery in the feces close to the $85.0 \pm 8.3 \%$ and correlation coefficient of $0.9236(\mathrm{P}<0.05)$ obtained by $\mathrm{TiO}_{2}$ (Table 4). Because it has a fecal recovery of $85.0 \pm 8.3 \%$ and a correlation coefficient of $0.9236(\mathrm{P}<0.05), \mathrm{TiO}_{2}$ is also efficient in the estimate of the total fecal DM production and consequently digestibility in sheep.

The fecal recovery of a marker is one of the greatest limitations in estimating digestibility through indirect methods, so recovery rates close to or above $90 \%$ are recommended (CABRAL et al., 2008). Similarly, results were obtained by Titgemeyer et al. (2001), which justifies the recommendation of external markers $\mathrm{TiO}_{2}$ and $\mathrm{Cr}_{2} \mathrm{O}_{3}$ in research with sugarcane top in diets for finishing sheep (Table 3). Those authors highlight $\mathrm{TiO}_{2}$ as an indigestible marker that can be used to estimate the digestibility of ruminants and that, unlike $\mathrm{Cr}_{2} \mathrm{O}_{3}$, can be added directly to the feed.

External markers $\mathrm{Cr}_{2} \mathrm{O}_{3}$ and $\mathrm{TiO}_{2}$ were evaluated by Ferreira et al. (2009) to estimate digestibility and proved the efficiency of these markers, concluding that their use will depend on factors such as cost and ease of use (daily management for supply).

Internal marker iDM and external markers chromium oxide $\left(\mathrm{Cr}_{2} \mathrm{O}_{3}\right)$ and titanium dioxide $\left(\mathrm{TiO}_{2}\right)$ are efficiently recovered in the feces, demonstrating to be effective in the estimate of the total fecal dry matter production aiming to estimate the digestibility of DM and nutrients by finishing sheep fed diets containing sugarcane-top hay. 


\section{REFERENCES}

ASSOCIATION OF OFFICIAL ANALYTICAL CHEMISTS - AOAC. Official methods of analysis of AOAC international. $19^{\text {th }}$.ed. Gaithersburg, MD, USA: Association of Analytical Communities, 2012.

BRITO, R.M.; SAMPAIO, A.A.; RESENDE, K.T.; FERNANDES, A.R.M.; HENRIQUE, W.; ROUTMAN, K.S. Avaliação de indicadores para estimativa das digestibilidades parciais e total de dietas em bovinos. Revista Brasileira de Zootecnia, v.36, n.2, p.445-451, 2007.

\section{CABRAL, L.S.; VALADARES} FILHO, S.C.; DETMANN, E.; ZERVOUDAKIS, J.T.; SOUZA, A.L.; VELOSO, R.G. Avaliação de indicadores na estimação da excreção fecal e da digestibilidade em ruminantes. Revista Brasileira de Saúde e Produção Animal [online], v.9, n.1, p.29-34, 2008.

CANESIN, R.C.; FIORENTINI, G.; BERCHIELLI, T.T. Inovações e desafios na avaliação na nutrição de ruminantes. Revista Brasileira de Saúde e Produção Animal [online], v.13, n.4, p.938-953, 2012.

CASALI, A.O.; DETMANN, E.; VALADARES FILHO, S.C.; PEREIRA, J.C.; FREITAS, S.G.; PAULINO, M.F. Influência do tempo de incubação e do tamanho de partículas sobre teores de compostos indigestíveis em alimentos e fezes bovinas obtidos por procedimento in situ. Revista Brasileira de Zootecnia, v37, n.2, p.335-342, 2008.
DETMANN, E.; SOUZA, A.L.;

GARCIA, R.; VALADARES FILHO, S.C.; CABRAL, L.S.;

ZERVOUDAKIS, J.T. Avaliação do vício de "tempo longo" de indicadores internos em ensaios de digestão com ruminantes. Arquivo Brasileiro de Medicina Veterinária e Zootecnia, v.59, n.1, p.182-188, 2007.

DETMANN, E.; VALADARES FILHO, S.C. On the estimation of nonfibrous carbohydrates in feeds and diets. Arquivo Brasileiro de Medicina Veterinária e Zootecnia, v.62, n.4, p.980-984, 2010.

DETMANN, E.; VALADARES FILHO, S.C.; BERCHIELLI, T.T.; CABRAL, L.S.; LADEIRA, M.M.; SOUZA, M.A.; QUEIROZ, A.C.; SALIBA, E.O.S.; PINA, D.S.; AZEVEDO, J.A.G. (Ed.). Métodos para análise de alimentos. Visconde do Rio Branco, MG: Suprema, 2012. $214 p$.

\section{FERREIRA, M.A.; VALADARES} FILHO, S.C.; SILVA, L.F.C.; NASCIMENTO, F.B.; DETMANN, E.; VALADARES, R.F.D. Avaliação de indicadores em estudos com ruminantes: estimativa de consumos de concentrado e de silagem de milho por vacas em lactação. Revista Brasileira de Zootecnia, v.38, n.8, p.1574-1580, 2009.

GOBBI, K.F.; GARCIA, R.; GARCEZ NETO, A.F.; PEREIRA, O.G.; BERNARDINO, F.S.; ROCHA, F.C. Composição química e digestibilidade in vitro do feno de Brachiaria decumbens Stapf. tratado com ureia.

Revista Brasileira de Zootecnia, v.34, n.3, p.20-725, 2005. 
KOZLOSKI, G.V.; MESQUITA, F.R.; ALVES, T.P.; CASTAGNINO, D.S.; STEFANELLO, C.M.; SANCHEZ, L.M.B. Avaliação do uso de frações indigestíveis do alimento como indicadores internos de digestibilidade em ovinos. Revista Brasileira de Zootecnia, v.38, n.9, p.1819-1823, 2009.

KOZLOSKI, G.V.; PEREZ NETO, D.; OLIVEIRA, L.; MAIXNER, A.R.; LEITE, D.T.; MACCARI, M.; BRONDANI, I.L.; SANCHEZ, L.M.B.; QUADROS, L.F. Uso de óxido de cromo como indicador da excreção fecal de bovinos em pastejo: variação das estimativas em função do horário de amostragem. Ciência Rural, v.36, n.2, p.599-603, 2006.

LICITRA, G.; HERNANDEZ, T.M.; VAN SOEST, P.J. Standardization of procedures for nitrogen fractionation of ruminant feeds. Journal of Animal Science and Technology, v.57, n.4, p.347-358, 1996.

MAEDA, E.M.; ZEOULA, L.M.; GOMES, H.C.C.; JACOBI, G.; SIMIONI, F.L.; OLIVEIRA, R.A. Avaliação de indicadores usados nos estudos de ingestão e digestibilidade em bovinos e bubalinos. Archivos de Zootecnia, v.60, n.229, p.123-131, 2011.

NATIONAL RESEARCH COUNCIL NRC. Nutrient requirements of small ruminants: sheep, goats, cervids, and new world camelids. $7^{\text {th }}$.ed. Washington: National Academy Press, 2007. 362p.

OLIVEIRA, K.; COSTA, C.; BITTAR, C.M.M.; SANTOS, V.P.; OLIVEIRA, V.A.B.; SÁ, J.C. Indigestible cellulose and lignin in determining feces production and apparent digestibility in horses. Acta Science. Animal Science, v.34, n.3, p.267-272, 2012.
RIBEIRO, L.S.O.; PIRES, A.J.V.; CARVALHO, G.G.P.; CHAGAS, D.M.T. Degradabilidade da matéria seca e da fração fibrosa da cana-de-açúcar tratada com hidróxido de sódio ou óxido de cálcio. Revista Brasileira de Saúde e Produção Animal [online], v.10, n.3, p.573-585, 2009.

RODRIGUES, P.H.M.; GOMES, R.C.; SIQUEIRA, R.F.; MEYER, P.M.; RODRIGUES, R.R. Acurácia, precisão e robustez das estimativas da digestibilidade aparente da matéria seca determinada com o uso de indicadores em ovinos. Revista Brasileira de Zootecnia, v.39, n.5, p.1118-1126, 2010.

SALIBA, E.O.S.; RODRIGUEZ, N.M.; MORAIS, S.A.L.; VELOSO, D.P. Ligninas - métodos de obtenção e caracterização química. Ciência Rural, v.31, n.5, p.917-928, 2001.

SILVA, J.J.; SALIBA, E.O.S.; BORGES, I.; GONÇALVES, L.C.; RODRIGUEZ, N.M.; AROEIRA, L.J.M.; SILVA, A.G.M.; NASCIMENTO, F.J. Indicadores para estimativa de consumo total por novilhas holandês $\mathrm{x}$ zebu mantidas em confinamento. Revista Brasileira de Saúde e Produção Animal [online], v.11, n.3, p.838-848, 2010.

SOUZA, J.; BATISTEL, F.; WELTER, K.C.; SILVA, M.M.; COSTA, D.F.; SANTOS, F.A.P. Evaluation of external markers to estimative fecal excretion, intake, and digestibility in dairy cows.

Tropical Animal Health and

Production, v.47, n.1, p.265-268, 2015.

STATISTICAL ANALYSIS SYSTEM - SAS. Statistical Analysis System User's Guide: Statistics. Version 9,1. SAS Institute Inc., Cary, NC, USA: SAS Institute Inc, 2002. 
TITGEMEYER, E.C.; ARMENDARIZ, C.K.; BINDEL, D.J.; GREENWOOD, R.H.; LOEST, C.A. Evaluation of titanium as a digestibility marker for cattle. Journal of Animal Science, v.79, n.4, p.1059-1063, 2001.

TORRES, L.C.L.; FERREIRA, M.A.; GUIM, A.; VILELA, M.S.; GUIMARÃES, A.V.; SILVA, E.C. Substituição da palma-gigante por palma-miúda em dietas para bovinos em crescimento e avaliação de indicadores internos. Revista Brasileira de Zootecnia, v.38, n.11, p.2264-2269, 2009.

VAN SOEST, P.J.; ROBERTSON, J.B.; LEWIS, B.A. Carbohydrate methodology, metabolism, and nutritional implications in dairy caltle. Journal of Dairy Science, v.74, n.1, p.3583-3597, 1991.

VAN SOEST, P.J. Use of detergents in the analysis of fibrous feed. II. A rapid method for the determination of fiber and lignin. Journal of the AOAC, v.46, n.5, p.829-835, 1963.

WEISS, W.P.; CONRAD, H.R.; PIERRE, N.R.S. A theoretically-based model for predicting total digestible nutrient values of forages and concentrates. Journal of Animal Science and Technology, v.39, n.1-2, p.95-110, 1992.

ZEOULA, L.M.; PRADO, I.N.; DIAN, P.H.M.; GERON, L.J.V.; CALDAS NETO, S.F.; MAEDA, E.M.; PERON, P.D.P.; MARQUES, J.A.; FALCÃO, A.J.S. Recuperação fecal de indicadores internos avaliados em ruminantes.

Revista Brasileira de Zootecnia, v.31, n.4, p.1865-1874, 2002.

Data de recebimento: 09/07/2015

Data de aprovação: 06/12/2016 